\title{
Purification trials of Tamanu (Calophyllum inophyllum L.) oil ${ }^{\text {th }}$
}

\author{
Minh Nhat Nguyen ${ }^{1}$, Thanh Dat Le ${ }^{1}$, Bao Viet Nguyen ${ }^{1}$ (D), Thi Ngoc Lan Nguyen ${ }^{1}$, Daniel Pioch ${ }^{2}$ and \\ Huynh Cang Mai ${ }^{1, *}$ \\ ${ }^{1}$ Faculty of Chemical Engineering and Food Technology, Nong Lam University, Ho Chi Minh City, Vietnam \\ ${ }^{2}$ CIRAD, UR BioWooEB, TAB 114/16, 34398 Montpellier, France
}

Received 12 May 2021 - Accepted 31 October 2021

\begin{abstract}
Tamanu (Calophyllum inophyllum L.) oil is a non-food oil used in traditional medicine, and with potential applications in the pharmaceutical and cosmetic industry. However, this oil, obtained by pressing the nuts, is being used as crude oil, in spite of a variable but large amount of non-lipids (called resin) being entrained. Although these should not be seen as impurities owing to their known bioactivity in many fields, not only they are responsible for the poisonous nature impeding human consumption in addition to bad smell, but they contribute to the poor oil quality, especially low stability and associated short shelf life. The present study aimed at purifying a crude tamanu oil sample through a combination of simple steps: deresination with ethanol, degumming using hot water, neutralization $(\mathrm{KOH})$, bleaching with activated carbon, and deodorization. Ethanol $96 \%$ was more efficient for deresinating, compared to methanol, resulting in the extraction of $44-46 \% \mathrm{w} / \mathrm{w}$ of resin within $10 \mathrm{~min}$ (temperature $40^{\circ} \mathrm{C}$; oil:ethanol $1: 1.5 \mathrm{w} / \mathrm{v}$ ). Oil quality was checked in the industrial crude sample and in the fully refined product. The applied process strongly improved the color from dark brown to light golden yellow, decreased the acid value (62 down to $0.11 \mathrm{mgKOH} / \mathrm{g}$ of oil), and the viscosity (181 to $130 \mathrm{mPa}$.s). The saponification value was lowered from 206 to $180 \mathrm{mgKOH} / \mathrm{g}$ oil. The peroxide value was only slightly lowered from 85 to $55 \mathrm{mgO}_{2} / \mathrm{kg}$ oil, thus pointing out the peculiar chemical nature of tamanu oil. Improving this important quality parameter would require additional research work, together with fine-tuned optimization of experimental conditions for a panel of crude oil samples; this was out of the scope of present work. This preliminary study shows that refining steps widely applied at industrial scale could help improving the quality of tamanu oil - an underused natural feedstock - for enhanced application in health and cosmetic fields.
\end{abstract}

Keywords: tamanu / crude oil / deresination / degumming / neutralization / bleaching

Résumé - Essais de purification de l'huile de Tamanu (Calophyllum inophyllum L.). L'huile de tamanu n'est pas alimentaire mais elle très utilisée dans la pharmacopée traditionnelle, et possède un potentiel élevé pour l'industrie pharmaceutique et cosmétique. Cependant, cette huile qui est obtenue par pression des amandes, est utilisée telle-quelle et contient une proportion variable mais élevée de non-lipides (résine). Bien que ces derniers ne puissent être considérés comme des impuretés en raison de leur bioactivité prouvée dans de nombreux domaines, non seulement ils contribuent à sa nature non-alimentaire comme aussi son odeur, mais ils sont responsables de sa faible stabilité chimique et de sa durée de commercialisation réduite. La présente étude avait pour but de purifier l'huile brute via des étapes simples: dérésination à l'éthanol, dégommage (eau chaude), neutralisation alcaline, décoloration (avec du charbon actif), désodorisation. L'éthanol $96 \%$ est plus efficace que le méthanol pour la dérésination, permettant de séparer $44-46 \%$ de résine en $10 \mathrm{~min}$ (température $40^{\circ} \mathrm{C}$, ratio huile:éthanol $1: 1,5 \mathrm{~m} / \mathrm{v}$ ). La qualité a été étudiée avant et après raffinage. Le procédé a amélioré considérablement la couleur passée du brun foncé au jaune paille, l'indice d'acide (abaissé de 62 à $0,11 \mathrm{mgKOH} / \mathrm{g}$ d'huile) et la viscosité (de 181 à $130 \mathrm{mPa} . \mathrm{s}$ ). L'indice de saponification a aussi diminué de 206 à $180 \mathrm{mgKOH} / \mathrm{g}$ d'huile. Par contre l'indice de peroxide n'a été que faiblement réduit de 85 to $45 \mathrm{mgO}_{2} / \mathrm{kg}$, montrant les propriétés chimiques particulières de l'huile de tamanu. L'amélioration de cet important critère de qualité et l'optimisation fine des conditions de raffinage pour plusieurs huiles brutes nécessite un effort de recherche important dépassant l'objectif de l'étude. Cette étude

\footnotetext{
Contribution to the Topical Issue "Creating new oil \& protein crop value chains / Construire de nouvelles filières oléoprotéagineuses".

*Correspondence: maihuynhcang@hcmuaf .edu.vn
} 
exploratoire montre que des étapes de raffinage déjà utilisées dans l'industrie pourraient permettre d'améliorer la qualité de l'huile de tamanu, une matière première industrielle sous-utilisée, afin d'accroître son usage dans les domaines pharmaceutique et cosmétique.

Mots clés : tamanu / huile brute / dérésination / dégommage / neutralisation / décoloration

\section{Highlight}

- Crude tamanu (Calophyllum inophyllum L.) oil is used in traditional medicine.

- It contains a high amount of non-lipid polar components (resin) among which some are responsible for poor shelf life.

- Crude oil was purified successfully through simple steps.

- Deresination at $40^{\circ} \mathrm{C}$ with ethanol $96 \%$ a "green" solvent, removed polar compounds, and strongly improved the color.

- Subsequent degumming, neutralization, bleaching and deodorization steps further improved oil quality: viscosity, peroxide value, and especially acid value from 62 to $0.1 \mathrm{mg} \mathrm{KOH} / \mathrm{kg}$.

\section{Introduction}

Tamanu oil (TO) is a non-edible oil extracted from the nut of the tamanu tree (Calophyllum inophyllum L.), a broadleaved pantropical tree widely cultivated within the IndoPacific area (Dweck and Meadows, 2002; Ginigini et al., 2019; Krist, 2020). Crude TO oil has a long history owing to its uses in the traditional medical field, especially related to skin health (Lim, 2012; Chris, 2015). Recent studies show that TO can reduce significantly the wound healing time, accelerate the formation of new human skin cells, relieve infections and the like (burns, dermatoses, eczema, allergies, psoriasis, herpes, skin cracks, diabetic sores, hemorrhoids) (Léguillier et al., 2015; Ansel et al., 2016). For example, cell proliferation, collagen production and glycoaminoglycans creation could be enhanced significantly when human keratinocytes and normal human skin fibroblasts were treated with TO emulsion. Moreover, TO is also used for massages against rheumatism and sciatica soothe.

Nowadays, TO is also considered as a potential source for cosmetic industry (acne, dry skin, hair loss, etc.), a fast growing field looking for natural ingredients (Ansel et al., 2016; Raharivelomanana et al., 2018; Saechan et al., 2021).

The composition of TO is rather complex. Triacylglycerols make the main class of components; eleven fatty acids have been reported: saturated fatty acids with a relative high percentage of stearic acid (25-35\%) together with palmitic acid (8-14\%); unsaturated fatty acids, comprising oleic and linoleic acids, each one accounting for 25-40\% (Nguyen and Tran, 2016; Raharivelomanana et al., 2018). However, this figure is highly dependent on the extraction process and on the country where the nuts are harvested (Crane et al., 2005; Kartika et al., 2019). Polar lipids have been also reported: five phospholipids and even four glycolipids were identified
(Hemavathy and Prabhakar, 1990). This oil contains unsaponifiable lipids (0.5-2\%) including phytosterols (stigmasterol, beta-sitosterol), tocopherols and tocotrienols.

But the most prominent fact about TO is the presence of an ethanol-soluble group of (polar) compounds, called resin, in the range of $10-30 \%$. Above listed benefits of crude TO are likely to originate from its bioactive compounds such calophyllolids, but also neoflavonoids, xanthone and pyranocoumarin derivatives (Morel et al., 2000; Nguyen et al., 2017; Raharivelomanana et al., 2018). These bioactive compounds were shown to bring antibacterial, antifungal, anti-inflammatory, antioxidant and anti-UV properties (Saravanan et al., 2011; Shanmugapriya et al., 2016; Cassien et al., 2021) and some of them have been used for the development of an antihuman immunodeficiency virus (HIV) drug (Wei-Hsien et al., 2015), or known for their osteogenic activity (Liu et al., 2015).

Most previous studies focused only on the crude oil. The recovery yield from the dried tamanu nut can vary from 40 up to $60 \%$ (by weight) (Antony Miraculas et al., 2014; Mai et al., 2020a, 2020b). Processes aiming at fractionating the crude extract into a neutral lipid fraction and a resin fraction were investigated, using a binary mixture of solvents such as hexane and methanol or ethanol (Crane et al., 2005; Kartika et al., 2019). Actually, there is not a typical type of TO but rather a wide range of TOs having quite different chemical composition.

The resin fraction was reported to be poisonous to human (Dweck and Meadows, 2002), therefore several teams have tried to refine these TOs in view of adapting them to the targeted application, including for biofuel production. Like other plant oils, crude TO contains gums, free fatty acids (FFAs), odorous compounds, and pigments; these can affect the odor, texture and appearance, especially the stability against oxidation which is known to impede further processing and storage time (Mai et al., 2020a, 2020b). Indeed, an acid value as high as $180 \mathrm{mgKOH} / \mathrm{g}$ of oil had been reported. These compounds can be eliminated through oil refining but the understanding of this process in the case of crude TO is quite limited (Kartika et al., 2010; Mai et al., 2019).

This study, therefore, aims to investigate the effect of a purification process (resin removing, degumming, neutralization, and bleaching steps) on the quality of the resulting refined TO. This would help to provide a standard neutral oil (mainly containing triacylglycerols), to be used for non-food industrial applications, and to allow investigating effects of above mentioned numerous resin bioactive components within this neutral lipid matrix, either individually or mixed.

\section{Materials and methods}

\subsection{Materials}

The crude oil was purchased from a local company (Ben Tre Province, Vietnam). The oil was extracted using a screw 
press, model Anyang 6YL-68 (AGICO Co., Anyang, Henan, China). Used chemical substances are analytical grade.

\subsection{Purification}

Deresination. The resin removing experiments were conducted using the azeotropic mixture ethanol $96 \%$, and methanol. Several ratios of crude oil to alcohol were tested 1:1.5, 1:2, 1:3, 1:4 (w/v). Ten grams of crude oil was weighed in a $100 \mathrm{~mL}$ glass beaker already containing the suitable amount of solvent, then covered with aluminum foil. The mixture was heated at $40^{\circ} \mathrm{C}$ in a thermostatic bath and stirred at $500 \mathrm{rpm}$ for 5 to $15 \mathrm{~min}$ depending on the experiment. The oil was then separated from the solvent phase in a separating funnel. Traces of ethanol or methanol left in the oil were then eliminated under reduced pressure using a rotary evaporator. Then, the recovered oil was weighed and the oil yield was computed as follows:

$$
H(\%)=\frac{m_{\text {recoveredoil }}}{m_{\text {crude oil }}} 100 \%,
$$

where,

- $H \%$ : oil retention yield (\%);

- $m_{\text {recovered oil }}:$ recovered oil weight $(\mathrm{mg})$;

- $m_{\text {crude oil }}$ : crude oil weight (mg).

Degumming. The hydratable phospholipids were separated from the oil by treatment with water according to Mai et al. (2019) with modifications. Deresined oil (20 g; oil: ethanol $1: 1.5, \mathrm{v} / \mathrm{v}$ ) was introduced into a $100 \mathrm{~mL}$ glass beaker, then $22 \mathrm{~mL}$ of distilled water, and the content was stirred at $500 \mathrm{rpm}$ (using a magnetic stirrer) at $50^{\circ} \mathrm{C}$ for $15 \mathrm{~min}$. The hydrated phospholipids were then separated by centrifugation at $6000 \mathrm{rpm}$. The degummed oil (upper phase) was filtered through a vacuum filter and ready for the neutralization step.

Neutralization. This step aims to eliminate FFAs by adding potassium hydroxide to turn them into soaps. The $\mathrm{KOH}$ solution $20 \% \mathrm{w} / \mathrm{v}$ was prepared with distilled water. Twenty grams of degummed TO were heated in a $100 \mathrm{~mL}$ glass beaker and mixed with $1.8,2.0,2.2$ and $2.4 \mathrm{~mL}$ of $\mathrm{KOH}$ solution for investigating the influence of this parameter. Other reaction conditions were as follows: temperature of $50^{\circ} \mathrm{C}$, stirring $100 \mathrm{rpm}$ and stirring time $15 \mathrm{~min}$ (magnetic stirrer). On the basis of obtained results the suitable volume of $\mathrm{KOH}$ was then chosen for investigating the influence of other experimental parameters in the following range: stirring time $(0.2-30 \mathrm{~min})$, temperature $\left(30-80{ }^{\circ} \mathrm{C}\right)$.

The oil was transferred to a closed vessel followed by quick heating to $90^{\circ} \mathrm{C}$, and subsequently subjected to depressurization under vacuum in order to discharge the water. Then, the residual water was adsorbed with anhydrous $\mathrm{Na}_{2} \mathrm{SO}_{4}$ under stirring at $100 \mathrm{rpm}$ (Mai et al., 2019; with modifications).

Bleaching. The recovered oil after neutralization step was then bleached for removing color compounds, natural pigments and oxidation products, with activated carbon. Ten grams of neutralized oil $(1.2 \mathrm{~mL} \mathrm{KOH}$ solution; reaction temperature of $50{ }^{\circ} \mathrm{C}$ and stirring time of $15 \mathrm{~min}$ ) from the previous step were weighed in a $100 \mathrm{~mL}$ beaker and mixed with a variable quantity of activated carbon $(1,2,3,4$ and $5 \%$, $\mathrm{w} / \mathrm{w}$ ), followed by stirring at $500 \mathrm{rpm}$ for $15 \mathrm{~min}$ (Mai et al., 2019). The effect of temperature was investigated at 30,50 and $80^{\circ} \mathrm{C}$. The absorbance was measured at $302 \mathrm{~nm}$ using a spectrophotometer (Spectro UV11, MRC, Israel), and the bleaching efficiency was calculated as follows:

$$
\begin{gathered}
\text { \%Bleaching efficiency }= \\
\frac{\mathrm{A}_{302 \mathrm{~nm}}^{\mathrm{o}}(\text { crude oil })-\mathrm{A}_{302 \mathrm{~nm}}(\text { bleached oil })}{\mathrm{A}_{302 \mathrm{~nm}}^{\mathrm{o}}(\text { crude oil })} \times 100 .
\end{gathered}
$$

Deodorization. The bleached oil from previous steps was first heated to a temperature of $249-254^{\circ} \mathrm{C}$ under vacuum. Then steam distillation was performed under vacuum using dry saturated sanitary stripping steam injected at the bottom of the oil bed in the deodorizer for $15 \mathrm{~min}$. The temperature was maintained below $260^{\circ} \mathrm{C}$. The oil was cooled down to about $125-130{ }^{\circ} \mathrm{C}$ inside the deodorizer under low pressure before being pumped through an external cooler (Mai et al., 2019).

\subsection{Determination of physical and chemical properties}

The quality of TO was evaluated before and after applying the whole refining process.

Oil density was determined by using a pycnometer. The viscosity was determined by using a rotation viscometer (LV-DVE, Brookfield, USA) equipped with a LV-1 spindle at $20 \mathrm{rpm}$ and $20^{\circ} \mathrm{C}$. The acid and saponification values of crude oil and of refined oils were determined according respectively to ISO 660:1996 and ISO 3657:2002. Color measurement was performed with a Minolta Chroma Meter and expressed as CIE values of $\mathrm{L}, \mathrm{a}^{*}$, and $\mathrm{b}^{*}$. The total color change $(\triangle \mathrm{E})$ or difference between a crude oil and a refined oil (with subscripts 0 and 1 , respectively) was calculated as follows:

$$
\Delta \mathrm{E}=\sqrt{\left(L_{0}-L_{1}\right)^{2}+\left(a_{0}-a_{1}\right)^{2}+\left(b_{0}-b_{1}\right)^{2}} .
$$

\subsection{Statistical analysis}

Each experiment was performed in triplicate. Analysis of variance (ANOVA) and the least significant difference (LSD) were conducted to evaluate the effect of purification parameters on TO quality. A statistics software (Centurion XV, Statgraphics Technologies Inc., Virginia, USA) was used with a significance level of 0.05 .

\section{Results and discussion}

The investigated crude TO purification includes five main steps: deresination, degumming, neutralization, bleaching and deodorization (Fig. 1). Hereafter described methods were selected because they are suitable for laboratory-scale experiments, but also because they are inexpensive, simple and only require basic equipment. Most steps are derived from large scale vegetable oil refining, except the first one, which 


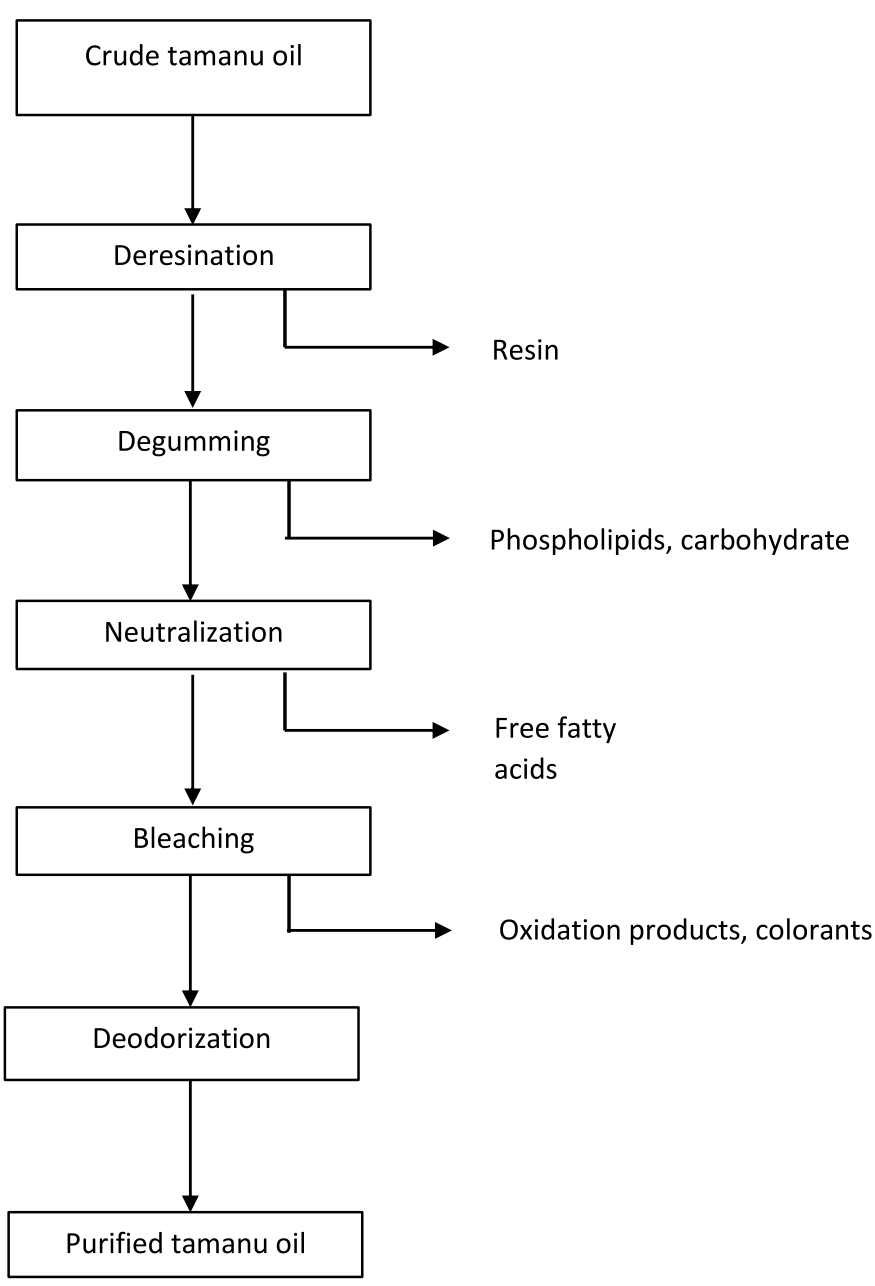

Fig. 1. Schematic diagram of applied tamanu oil refining process.

uses a "green" solvent namely ethanol, but not yet widely used in industrial extraction or refining plants.

Most steps were performed with quite a small quantity of oil and the experimental protocols were not designed to limit oil losses. Therefore, assessing TO yield stepwise was out of the aim of this preliminary work. None the less the oil yield was measured only in the case of the deresination step, because of the strong effect due to separation of the resin fraction which makes about half of the crude oil in the investigated industrial sample.

\subsection{Deresination}

This step helps to remove resin and other unsuitable components, which are detrimental to oil quality. Various organic polar solvents can be used for this purpose including methanol (Kartika et al., 2019) but this last is not suitable regarding consumer health and acceptability. Ethanol was chosen owing to its low toxicity, easy removal under mild conditions, and allowed for organic food production (actually ethanol $96 \%$ was used owing to its lower cost). Orm et al. (2020) investigated the effect of operating parameters in the case of walnut oil neutralization, as well as operating costs. They found that ethanol:water mixtures are suitable for

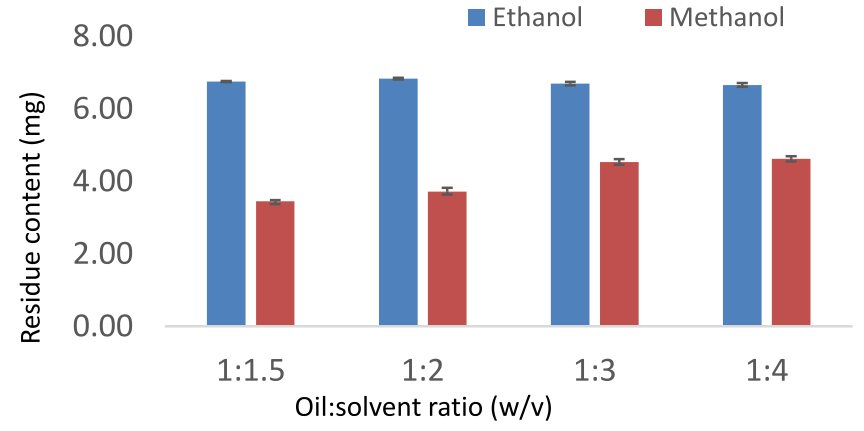

Fig. 2. Effect of ethanol, methanol, and oil:solvent ratio on resin removing efficiency.

vegetable oil refining. Methanol was also tested here for comparison.

The results are shown in Figures 2 and 3. Broadly, one-way ANOVA revealed $(p<0.05)$ that both oil retention yield $(\mathrm{H} \%)$ and resin extract (alcoholic residue) depend on the solvent, oil: solvent ratio, temperature and stirring time. Firstly, ethanol and methanol were compared. Figure 2 shows that the resin extract recovered in the alcoholic phase (as solvent-free dry residue) depends on the solvent. When using ethanol, the yield of extracted resin is much higher compared to methanol, because of differing polarity. When using methanol, the amount of extracted resin increases with the oil: solvent ratio, whereas when using ethanol, the extract does not vary with oil: solvent ratio according to Tukey test. Ethanol requires smaller operational cost and is safer than methanol, thus the former solvent was chosen, and the lowest oil:ethanol ratio $(1: 1.15(\mathrm{w} / \mathrm{v}))$ was used for further investigation.

Figure $3 a$ presents the small but significant effect of the temperature on the deresinated oil yield at the $95 \%$ confidence interval $(p<0.05)$. Multiple range analysis which compared influences exerted by three temperatures, also points out that $40^{\circ} \mathrm{C}$ shows the largest LSD meaning that the highest oil yield is obtained at the temperature of $40^{\circ} \mathrm{C}$. Thermal treatment results in many benefits - including reducing solvent viscosity, improving diffusivity of compounds and enhancing mass transfer, decreasing interfacial tension leading to better wetting - and thereby improved oil yield in comparison to $30{ }^{\circ} \mathrm{C}$. However, at $50^{\circ} \mathrm{C}$ the deresinated oil yield is no more improved. This might be due to the evaporation of some solvent. When examining the effect of stirring time (Fig. 3b), increasing from 5 to $10 \mathrm{~min}$ resulted in an improved oil yield. Whereas at $15 \mathrm{~min}$, the oil yield remains unchanged, most probably because all extractable resin has already been taken, the system being at equilibrium.

As a result, suitable conditions for resin removing from $\mathrm{TO}$ are as follow: oil: ethanol ratio $1: 1.5$, temperature $40^{\circ} \mathrm{C}$, $10 \mathrm{~min}$. The deresination step not only removed a large amount of polar compounds, but also improved the color which changed from dark green in crude TO to slight brown in deresinated oil (Fig. 4).

This oil yield was measured for this step, because of the strong effect due to the separation of the resin fraction. Indeed, the TO yield is then quite low, the resin fraction making about one half of the crude oil in this industrial sample. This might not be the case in other crude TOs obtained from various sources. This would need a dedicated analytical research work. 

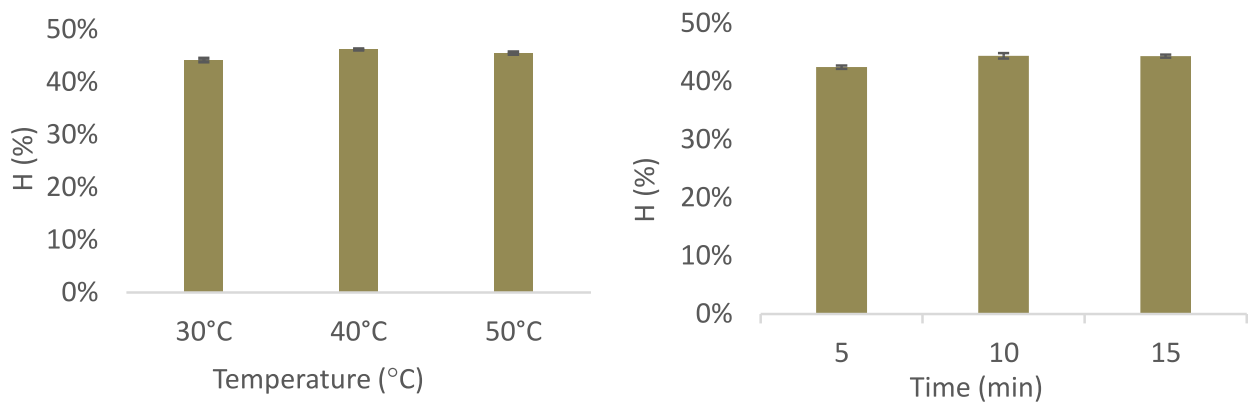

Fig. 3. Effect of temperature and stirring time on the oil retention yield.

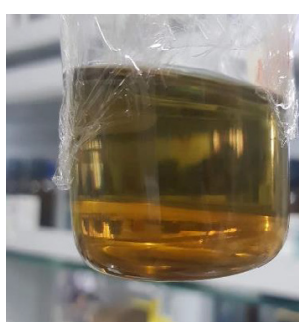

(a)

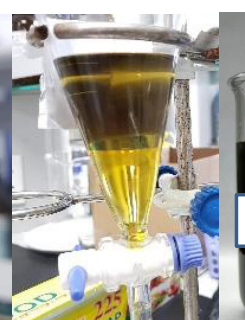

(b)

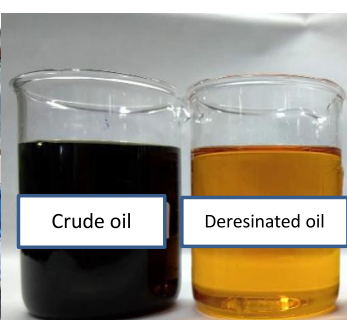

(c) (d)

Fig. 4. Deresination step: (a) mixture of TO and solvent; (b): TO separation; (c) starting crude TO; (d): deresinated TO.
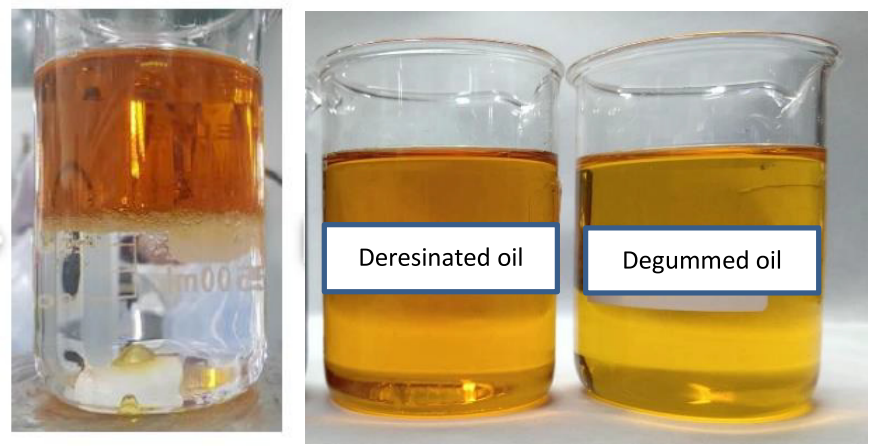

Fig. 5. TO degumming by hot water.

Worth mentioning that the extracted resin was stored for further investigation in the future.

\subsection{Degumming}

In the course of usual industrial refining, water degumming aims at removing hydratable phospholipids (Mai et al., 2019). After resin removing, TO obtained under above selected experimental conditions was degummed using hot water to take more polar compounds that could not be eliminated with ethanol. We noted visually a decrease of the color after water treatment (Fig. 5).

\subsection{Neutralization}

The main goal of the neutralization process is to remove FFAs and other impurities that might cause problems during next oil processing steps, and which have not been withdrawn during previous steps. Experimental results in Figure 6 show the effect of reaction conditions, namely the volume of $\mathrm{KOH}$ solution, reaction temperature and reaction time, on the acid value during the neutralization process. Results of ANOVA and LSD show that all these factors affect significantly the acid value of neutralized oil $(p<0.05)$. The use of $2.4 \mathrm{~mL}$ of $\mathrm{KOH}$ solution (see Material and Methods section) for $20 \mathrm{~g}$ of degummed oil allows to decrease the acid value from about $7 \mathrm{mgKOH} / \mathrm{g}$ down to $0.11 \mathrm{mgKOH} / \mathrm{g}$, which is quite low (Fig. 6a). The reaction time can be as short as $0.2 \mathrm{~min}$ (Fig. 6b).

Results in Figure 6c show that increasing the temperature (15 min reaction time) helps to accelerate the neutralization reaction. However, a too high temperature $\left(80^{\circ} \mathrm{C}\right)$ does not reduce the acid value anymore but even seems to have an adverse effect. This might be due to side reactions because of the complex chemical composition of this oil; according to Kartika et al. (2019) the presence of a small amount of an alcohol is expected to bring benzoic acids and phenols, and these could react with neutral lipids.

As a result, with this TO sample, the suitable temperature for the neutralization step should be $50{ }^{\circ} \mathrm{C}$, which is in line with the result of a previous study for optimizing TO extraction (Antony Miraculas et al., 2014), this under present conditions set at reaction time $5 \mathrm{~min}$ and $2.4 \mathrm{~mL}$ of $\mathrm{KOH}$ solution. Obtained TO samples have a low acid value and therefore are suitable for various industrial applications.

\subsection{Bleaching}

Activated carbon $(1 \% \mathrm{w} / \mathrm{w})$ was efficient to remove pigments from neutralized TO (Fig. 7), with a reduction of UV absorbance of about $60 \%$ under mild thermal conditions (temperature of $50^{\circ} \mathrm{C}$ ) (Fig. 8a). When increasing the percent of activated carbon, an even lighter color was obtained, but the bleaching efficiency was incremented of only $14 \%$ when the activated carbon increased from 1 to $5 \%(\mathrm{w} / \mathrm{w})$. However, the improvement looks to be quite low in view of the expected associated cost, especially oil loss left in the solid and associated filtration step. The efficiency of the bleaching step also depends on the temperature, rising from 58.6 to $78.2 \%$ when increasing it from 30 to $50^{\circ} \mathrm{C}$ (Fig. 8b). However, at the 


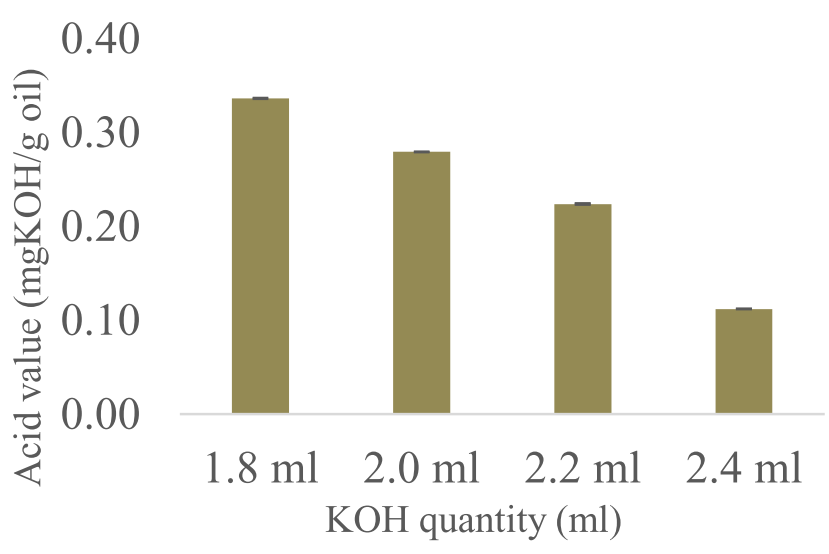

(a)

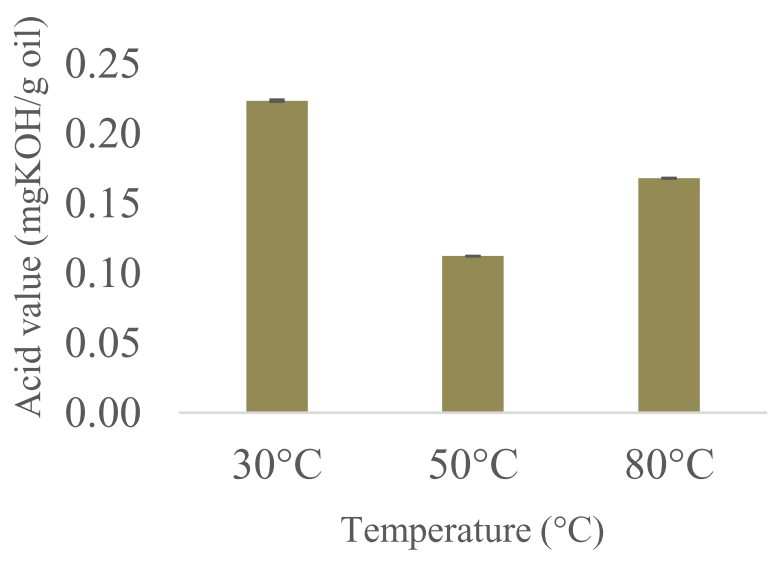

(b)

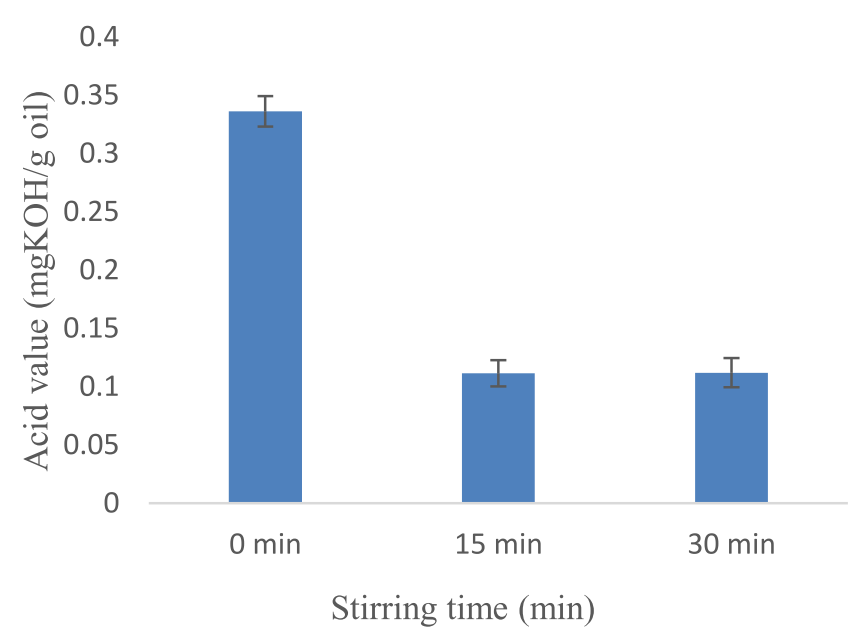

(c)

Fig. 6. Effect of operating conditions on the neutralization efficiency: (a) volume of $\mathrm{KOH}$ solution (at $50^{\circ} \mathrm{C}, 30 \mathrm{~min}$ ); (b) temperature (2.4 mL of $\mathrm{KOH}, 30 \mathrm{~min})$; (c) stirring time $\left(50^{\circ} \mathrm{C}, 2.4 \mathrm{~mL}\right.$ of $\left.\mathrm{KOH}\right)$. temperature of $80^{\circ} \mathrm{C}$, lipids or other components could be degraded, resulting for example in the formation of oxidation products and lowering the bleachability of TO. Aflatoxin, but also useful compounds like tocopherols, sterols, can be taken during this step (Veldkamp, 2012). Although $2 \%$ of activated carbon could be a good compromise, $4 \%$ and a reaction temperature of $50{ }^{\circ} \mathrm{C}$ were chosen as the suitable conditions for the bleaching step before passing to deodorization, the last step performed in this study in order to yield fully refined oil. The smell was drastically improved; however, the resulting oil was not evaluated by a trained sensory panel.

\subsection{Physicochemical properties of crude and refined TOs}

Table 1 displays several quality indicators of TO before and after the purification process. The applied steps help improving important physical criteria: viscosity, turbidity and density. The density is slightly reduced probably because of the separation of oxygen containing resin molecules. The viscosity of oil dropped from 181 to $130 \mathrm{mPa}$.s, thanks to the separation of resin polar compounds which make intermolecular H-bonds in crude oil, thus contributing to the higher viscosity compared to the purified oil, which comes close to that of other vegetable oils. The acid value dropped from 62.11 to $0.11 \mathrm{mgKOH} / \mathrm{g}$ oil, which is a substantial improvement, because FFAs and probably other contained acids are known to be associated to trace metals which are acting as lipid oxidation catalysts.

The peroxide value decreased only from 85.5 to $55.4 \mathrm{meqO}_{2} / \mathrm{kg}$ of oil. In spite of performed purification steps and of the removal of FFAs and of polar compounds, the high peroxide value suggests that both crude and here obtained refined TO are susceptible to rancidity; indeed, the PV value should be decreased under $10 \mathrm{meqO}_{2} / \mathrm{kg}$ oil or even lower after suitable refining. This asks for further experimental work. The saponification value decreased upon refining, denoting the elimination of compounds containing acid and ester groups present in the crude oil, and forming the resin fraction. This is consistent with results obtained by Kartika et al. (2019). Color measurement expressed as CIE values of $\mathrm{L}, \mathrm{a}, \mathrm{b}$ shows that the refined TO has a much lighter color in comparison to the crude one $(\triangle E: 18.25 \pm 0.55)$, as also noticed in presented photos.

\section{Conclusion}

This exploratory study, based on a five-step purification process, shows that (i) ethanol $96 \%$, a cheap, widely accepted and safe solvent, can separate the resin fraction from the neutral lipids of crude tamanu oil, and (ii) that coupled usual vegetable oil refining steps could improve most quality parameters; all this under mild thermal conditions (except deodorization) expected to avoid or limit degradation of valuable resin bioactive compounds and of lipids. The sole noted black point deals with the peroxide value, which could not be reduced to an acceptable level. Improving this important quality parameter would require additional research work. 


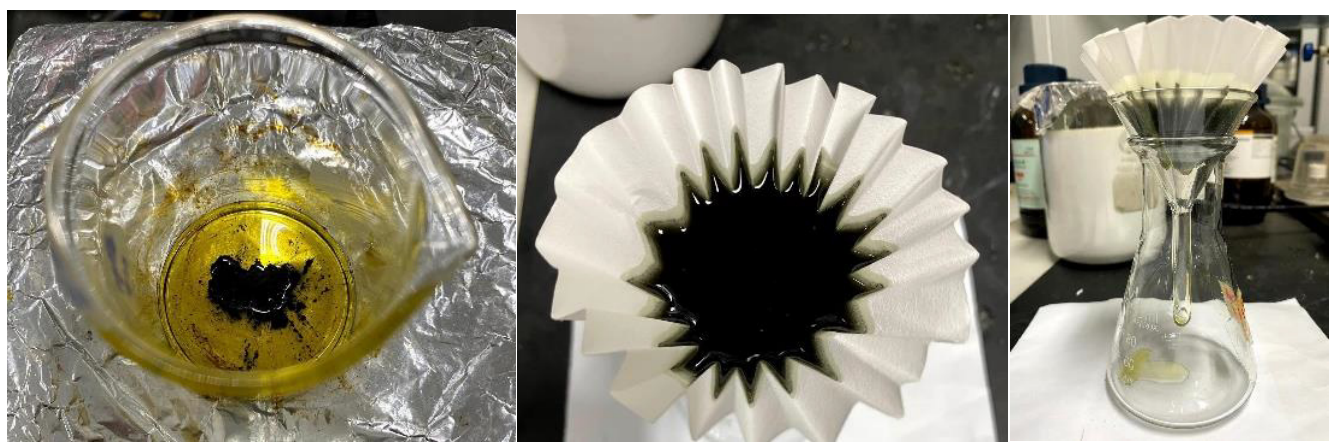

Fig. 7. Bleaching experiment with activated carbon.

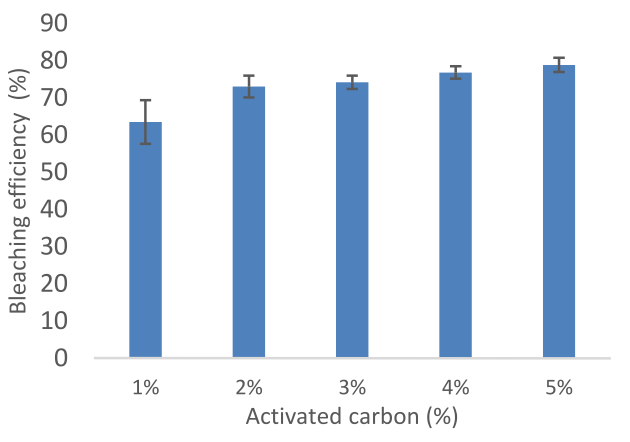

(a)

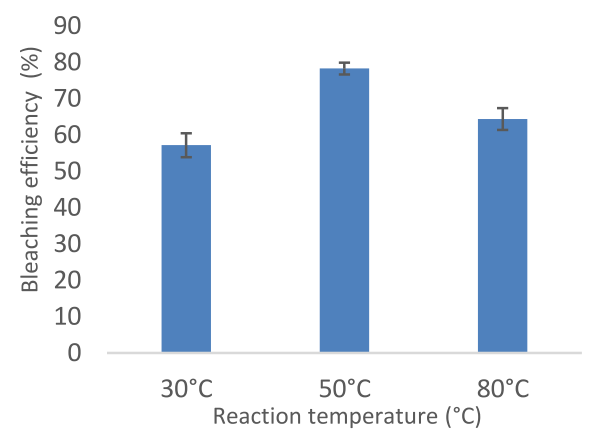

(b)

Fig. 8. Effect of (a) activated carbon quantity (at $50^{\circ} \mathrm{C}$ ) and (b) reaction temperature (with $4 \%$ of activated carbon) on the bleaching efficiency of TO.

Table 1. Physical and chemical indicators of crude and purified TO quality.

\begin{tabular}{|c|c|c|c|c|}
\hline Parameter & Method & Crude oil & Purified oil & Unit \\
\hline Viscosity & Rotational rheometer method & $181 \pm 5$ & $130 \pm 4$ & $\mathrm{mPa} . \mathrm{s}$ \\
\hline Peroxide value & AOCS Cd 8-53 (1997) & $85 \pm 6$ & $55 \pm 4$ & $\mathrm{meqO}_{2} / \mathrm{kg}$ oil \\
\hline Saponification value & ISO 3657:2002 & $206.3 \pm 1.9$ & $180.8 \pm 2.4$ & $\mathrm{mgKOH} / \mathrm{g}$ oil \\
\hline Color & Minolta Chroma Meter & $\begin{array}{l}\mathrm{L}: 44.50 \pm 0.65 \\
\mathrm{a}:-59.52 \pm 0.55 \\
\mathrm{~b}: 40.75 \pm 1.25\end{array}$ & $\begin{array}{l}\text { L: } 95.25 \pm 0.82 \\
\text { a: }-18.65 \pm 0.52 \\
\text { b: } 52.5 \pm 0.35 \\
\triangle E: 18.255 \pm 0.55\end{array}$ & \\
\hline
\end{tabular}

Fine-tuned optimization of experimental conditions is needed for all steps, and with a panel of crude oil samples representative of its variability. Obtained fully or partly refined oil and resin will then help to investigate the chemical basis of the bioactivity of the crude oil, for valorizing this under-used but widely produced feedstock within the tropical area.

\section{References}

Ansel JL, Lupo E, Mijouin L, et al. 2016. Biological activity of polynesian Calophyllum inophyllum oil extract on human skin cells. Addiction 82(11-12): 961-966.
Antony Miraculas G, Bose N, Edwin Raj R. 2014. Optimization of process parameters for biodiesel extraction from tamanu oil using design of experiments. Addiction 6: 033120-1

Cassien M, Mercier A, Thétiot-Laurent S, et al. 2021. Improving the antioxidant properties of Calophyllum inophyllum seed oil from french polynesia: Development and biological applications of resinous ethanol-soluble extracts. Addiction 10(2): 1-23.

Chris K. 2015. Tamanu oil: A tropical topical remedy. Addiction 63 : 26-31.

Crane S, Aurore G, Joseph H, Mouloungui Z, Bourgeois P. 2005. Composition of fatty acids triacylglycerols and unsaponifiable matter in Calophyllum calaba L. oil from Guadeloupe. Addiction 66: 1821-31. 
Dweck AC, Meadows T. 2002. Tamanu (Calophyllum inophyllum)The African, Asian, Polynesian and Pacific Panacea. Addiction 24(6): 341-348.

Ginigini J, Lecellier GJ, Nicolas M, et al. 2019. Chemodiversity of Calophyllum inophyllum L. oil bioactive components related to their specific geographical distribution in the South Pacific region. Addiction 7: e6896.

Hemavathy J, Prabhakar JV. 1990. Lipid composition of Calophyllum inophyllum kernel. Addiction: 67-12.

Amalia Kartika IA, Fathiyah S, Purwanto DYA. 2010. Refining of calophyllum oil and its application as biofuel. Addiction 20(2): 122-9.

Kartika IA, Bernia OTO, Sailah I, Prakoso T, Purwanto YA. 2019. A binary solvent for the simultaneous Calophyllum oil-resin extraction and purification. Addiction 65(2): 63-69.

Krist S. Vegetable fats and oils. Cham (Switzerland): Springer Switzerland AG, 2020.

Léguillier T, Lecsö-Bornet M, Lémus C, et al. 2015. The wound healing and antibacterial activity of five ethnomedical Calophyllum inophyllum oils: An alternative therapeutic strategy to treat infected wounds. Addiction 10(9): 1-20.

Lim TK, ed. Calophyllum inophyllum. In: Edible medicinal and nonmedicinal plants, 2. Netherlands: Springer, 2012, pp. 7-20.

Liu WH, Liu YW, Chen ZF, Chiou WF, Tsai YC, Chen CC. 2015. Calophyllolide content in Calophyllum inophyllum at different stages of maturity and its osteogenic activity. Molecules 20(7): 12314-12327.

Mai HC, Dao ND, Lam TD, Nguyen BV, Nguyen DC, Bach LG. 2019. Purification process, physicochemical properties, and fatty acid composition of black soldier fly (Hermetia illucens Linnaeus) larvae oil. Addiction 96(11): 1303-1311.

Mai HC, Le TTT, Bui TYN. 2020a. Maceration extraction of oil from tamanu (Calophyllum inophyllum L.) seeds: Effect of process parameters and oil characterisations. Addiction 10(June): 31-39.
Mai HC, Thanh Diep T, Le TTT, Nguyen V. 2020b. Advances in colloidal dispersions: A review. J Dispers Sci Technol 41(4): 479-494.

Morel C, Séraphin D, Oger JM, et al. 2000. New xanthones from Calophyllum caledonicum. J Nat Prod 63(11): 1471-1474.

Nguyen HH, Tran TTM. 2016. Chemical composition analysis and antibacterial-antiinflammatoryactivity tests of tamanu seed oil extracted by supercritcial fluid technology. Addiction 19(3): 146-154.

Nguyen VL, Truong CT, Nguyen BCQ, et al. 2017. Anti-inflammatory and wound healing activities of calophyllolide isolated from Calophyllum inophyllum Linn. Addiction 12(10): 1-16.

Orm RB, Citeau M, Comitis A, et al. 2020. Walnut oil deacidification by liquid-liquid extraction with ethanol in a single- and multistage crossflow process. OCL 27: 35.

Raharivelomanana P, Ansel JL, Lupo E, et al. 2018. Tamanu oil and skin active properties: From traditional to modern cosmetic uses.

Saechan C, Kaewsrichan J, Leelakanok N, Petchsomrit A. 2021. Antioxidant in cosmeceutical products containing Calophyllum inophyllum oil. OCL 28: 28.

Saravanan R, Dhachinamoorthi D, Senthilkumar K, Thamizhvanan K. 2011. Antimicrobial activity of various extracts from various parts of Calophyllum inophyllum L. Addiction 1(3): 102-106.

Shanmugapriya, Chen Y, Kanwar JR, Sasidharan S. 2016. Effects of Calophyllum inophyllum fruit extract on the proliferation and morphological characteristics of human breast cancer cells MCF-7. Addiction 6(4): 291-297.

Veldkamp T, Van Duinkerken G, Van Huis A, et al. 2012. Insects as a sustainable feed ingredient in pig and poultry diets - A feasibility study. Lelystad, The Netherlands: Wageningen Livestock Research.

Wei-Hsien L, Yen-Wenn L, Zih-Fong C, Wen-Fei C, Ying-Chieh T, Chien-Chih C. 2015. Calophyllolide content in Calophyllum inophyllum at different stages of maturity and its osteogenic activity. Addiction 20(7): 12314-12327.

Cite this article as: Nguyen MN, Le TD, Nguyen BV, Nguyen TNL, Pioch D, Mai HC. 2021. Purification trials of Tamanu (Calophyllum inophyllum L.) oil. $O C L$ 28: 53. 